OECDpublishing

MOBILISING INSTITUTIONAL INVESTOR CAPITAL FOR CLIMATE-ALIGNED DEVELOPMENT

OECD DEVELOPMENT POLICY PAPERS

January 2021 No. 35 

OECD Development Policy Papers

January 2021 - No. 35

\section{Mobilising Institutional Investor Capital for Climate-Aligned Development}

By Håvard Halland, Adam Dixon, Soh Young In, Ashby Monk and Rajiv Sharma 


\section{2 |}

This work is published under the responsibility of the Secretary-General of the OECD. The opinions expressed and arguments employed herein do not necessarily reflect those of the OECD, its Development Centre or of their member countries.

This document, and any map included herein, are without prejudice to the status of or sovereignty over any territory, to the delimitation of international frontiers and boundaries and to the name of any territory, city or area.

This document was authorised for publication by Mario Pezzini, Director of the Development Centre and Special Advisor to the OECD Secretary-General on Development.

Keywords: Institutional Investors, Blended Finance, Strategic Investment Funds, Green Banks, Development Finance Institutions, Sustainable Finance, Climate Finance

JEL Classification: O10, O19, G23, Q54

(C) OECD 2021 


\section{Abstract}

Financing from institutional investors will be critical to achieving the sustainable development goals (SDGs) and curbing climate change. However, these large investors have been largely absent from multilateral initiatives to mobilise private capital. Partly as a result, such initiatives have been unable to reach the scale required for development finance to go "from billions to trillions". Successful mobilisation of private capital - including from institutional investors - has instead frequently taken place at the local level, by strategic investment funds and some green banks. This is likely due to advantages of being a local investor, including risk assessment, networks and "boots on the ground", as well as the design of mandates, structure, governance, and staffing. At the same time, some institutional investors have been changing their modus operandi, from an intermediary to a collaborative model, and are re-localising their operations. The elimination of financial intermediaries with a short-term focus removes a bottleneck between two categories of long-term investors - institutional investors and multilateral finance institutions -, and opens new opportunities for collaboration. To take advantage of such opportunities, multilateral finance institutions will likely need to deepen their integration with the collaborative model and work closely with successful strategic investment funds and green banks. 


\section{Foreword}

The United Nations Intergovernmental Panel on Climate Change (IPCC) has warned that, to avoid the direst consequences of climate change, societies must make social and economic changes on a scale with no documented historic precedent. Institutional investors - like pension funds, sovereign wealth funds, and insurance companies - hold significant financial firepower to address climate change. They can and should play a crucial role in shifting investment and economic activities towards a low-carbon pathway.

However, as multilateral finance institutions seek to mobilise private capital at a scale relevant to climate change, institutional investors have been largely absent from such initiatives. Furthermore, multilateral finance institutions have had only modest success in mobilising private capital, and the amounts mobilised fall far short of what is required to achieve climate objectives and attain the sustainable development goals.

In general, multilateral finance institutions inhabit a different world from the institutional investors whose capital they seek to mobilise. This publication argues that multilateral finance institutions must begin looking to large institutional investors as their partners and clients. To foment such collaboration and partnerships, multilateral finance institutions would need to implement fundamental reforms.

Multilateral engagement to mobilise private capital has so far focused mainly on financial instruments, such as guarantees and green bonds. This publication proposes that multilateral finance institutions would need to focus more on institutional and governance aspects, related to the collaboration with institutional investors and local strategic investors. To enhance their attractiveness as partners for institutional investors, multilateral finance institutions need to strengthen their capacity to add value for these investors, by assisting them in assessing risk in new sectors and geographies, and help relieve bottlenecks to investing in borderline regions and sectors. Multilateral finance institutions would also need to build investor confidence that their collaboration with institutional investors is based on commercial principles of return maximisation, and that joint investments benefit from well-defined investor protections grounded in the multilaterals' mandate, governance, and practice.

Multilateral finance institutions could look to well-functioning strategic investment funds and green banks for examples of successful private capital mobilisation. These new types of financial institutions have governance structures that emulate core aspects of decision making in private financial institutions. While functioning within a policy-based mandate, their operations are consistent with the commercial principles and objectives that drive private investment.

Finally, efforts to mobilise private capital would benefit from a differentiated approach. Some geographies, or sectors within specific geographies, will continue to be the remit mainly of public finance, impact investors, and philanthropy. When seeking to mobilise capital from institutional investors, multilaterals should focus on sectors and regions where this is plausible - where the return-risk bargain is favourable to commercial private investment, and scale is sufficient for large investors. This would also serve to protect the AAA credit ratings of multilateral development banks, while expanding private capital mobilisation in geographies and sectors where this can be done at a scale relevant to curbing climate change.

This work contributes to the Development Centre's Programme of Work and Budget 2019-20 output area B: Competitive Economies. In particular, it is an intermediary output to the activities of the Policy Dialogue on Natural Resource based Development (B2) related to supporting developing countries' transition to a low-carbon economy. It also complements the Development Centre's work on the OECD Compendium of Policy Good Practices for Quality Infrastructure Development. The publication aims to contribute to the OECD's broader efforts to advance understanding of financing options for the low-carbon energy transition, including the mobilisation of private capital for development finance, and of institutional investor capital for green infrastructure.

\section{Mario Pezzini}

Director of the OECD Development Centre

and Special Advisor to the OECD Secretary-General on Development 


\section{Acknowledgements}

This publication was authored by: Håvard Halland, Senior Economist at the Organisation for Economic Co-operation and Development (OECD) Development Centre; Adam Dixon, Associate Professor of Globalisation and Development at Maastricht University; Soh Young In, Research Engineer at the Global Project Center and the Precourt Institute for Energy, Stanford University; Ashby Monk, Executive Director, and Rajiv Sharma, Research Director, of the Stanford Global Projects Center, Stanford University.

The authors are grateful to Federico Bonaglia, Deputy Director of the OECD Development Centre, for his support and guidance on this publication. The authors would also like to thank Christian Racicot, CEO of the Institutional Investors Roundtable, for his input to section 6 and the following individuals for very useful comments on previous versions of the publication: Paul Horrocks, Michel Noel, Jens Sedemund, Silvana Tordo, Robert Youngman and Aayush Tandon, as well as Rumi Masih, Mark Moseley, Sanjay Peters, and other participants and organisers of the conference Infrastructure Growth \& Development, London, September 2018. Delphine Grandrieux, Parissa Nahani and Elizabeth Nash provided administrative support for the publication. 


\section{6}

\section{Table of contents}

Abstract 3

Foreword 4

$\begin{array}{ll}\text { Acknowledgements } & 5\end{array}$

$\begin{array}{ll}\text { Abbreviations and acronyms } & 7\end{array}$

1 Introduction 8

2 Local is the new global: Domestic blended finance institutions 11

Green banks $\quad 11$

Strategic investment funds $\quad 12$

3 Is the local blend better? 14

Local level mobilisation $\quad 14$

Mobilisation by multilateral development finance providers $\quad 16$

Local and multilateral: Different ways of mobilising 17

4 Localising global investors through collaboration 20

The benefits and challenges of collaboration $\quad 20$

$\begin{array}{ll}\text { Types of collaborative platforms } & 20\end{array}$

5 The collaborative engagement of multilateral development finance providers 22

6 Re-conceptualising blended finance through collaboration 23

7 Conclusions and further research $\quad 27$

$\begin{array}{ll}\text { Notes } & 28\end{array}$

$\begin{array}{ll}\text { References } & 30\end{array}$

Tables

$\begin{array}{lr}\text { Table 3.1. Multiplier estimates for green banks } & 15\end{array}$

Table 3.2. Capital multipliers of selected funds: preliminary estimates 16

Table 3.3. Multiplier for multilateral climate funds 17

Table 3.4. Comparative characteristics of blended finance institutions 18

Figure

Figure 6.1. Key relationships for MDB and DFI collaborative engagement 


\section{Abbreviations and acronyms}

$\begin{array}{ll}\text { CEFC } & \text { Clean Energy Finance Corporation (Australia) } \\ \text { CTF } & \text { Clean Technology Fund } \\ \text { DAC } & \text { Development Assistance Committee } \\ \text { CGD } & \text { Centre for Global Development } \\ \text { CGFS } & \text { Committee on the Global Financial System } \\ \text { DFI } & \text { Development Finance Institution } \\ \text { EMDEs } & \text { Emerging Markets and Developing Economies } \\ \text { GCF } & \text { Green Climate Fund } \\ \text { GEEREF } & \text { Global Energy Efficiency and Renewable Energy Fund } \\ \text { GEF } & \text { Global Environment Facility } \\ \text { GPC } & \text { Global Project Centre, at Stanford University } \\ \text { IMF } & \text { International Monetary Fund } \\ \text { LCR } & \text { Low-carbon and Climate-Resilient } \\ \text { LTIC } & \text { Long-Term Investors' Club } \\ \text { MCFs } & \text { Multilateral Climate Funds } \\ \text { MDB } & \text { Multilateral Development Banks } \\ \text { NIIF } & \text { National Investment and Infrastructure Fund } \\ \text { OECD } & \text { Organisation for Economic Co-operation and Development } \\ \text { PSW } & \text { Private Sector Windows } \\ \text { SSRN } & \text { Social Science Research Network }\end{array}$




\section{Introduction}

It is commonly argued that financing from institutional investors will be critical to achieving the sustainable development goals (SDGs) and curbing climate change (OECD, 2018[1]). However, whereas institutional investors are significantly engaged in green finance, they have been largely absent from the type of borderline investment opportunities addressed by blended finance - where market and government failures constitute barriers to otherwise profitable private investment. ${ }^{1}$ Private investors in blended finance deals are often impact investors, whose capital is already available for development finance and hence not "additional" (Convergence, 2017 $[2]$ ). Few institutional investors, according to the same study, take a prominent role in blended finance.

The critical role of institutional capital is illustrated by the magnitude of the challenge at hand. As emerging markets and developing economies (EMDEs) seek to expand energy access for their citizens and industries, the alignment of energy- and other infrastructure investment with climate needs will be essential to achieving the objectives of the Paris Agreement. In fossil fuel-rich EMDEs, an increasing share of energy investment will need to be redirected from the fossil fuels sector to clean-energy infrastructure. Global infrastructure needs, compatible with low-carbon and climate resilient development, amount to USD 6.9 trillion per year for the next 15 years, of which USD 3.9 trillion in developing countries (OECD, $2018[3])^{2}$ The investment gap for developing countries, or difference with the current level of around USD 1.4 trillion, is estimated at USD 2.5 trillion per year (UNCTAD, 2014[4]]).

Reflecting this challenge, the last few years have seen a strong drive, amongst national and donor governments, multilateral organisations, and development finance institutions, towards the mobilisation of private capital "from billions to trillions" (Development Committee, $\left.2015_{[5]}\right)$.

Currently, infrastructure in developing countries has a high share of government funding. Developing economies get $70 \%$ of infrastructure funding from government budgets, $20 \%$ from private investors, and $10 \%$ from multilateral development banks (MDBs). The equivalent numbers for industrialised economies are $40 \%$ government funding, 55\% private sector financing, and 5\% from MDBs (Alexander, 2018 ${ }_{[6]}$ ) (Marsh \& McLennan, 2017 $\left[{ }_{[7]}\right)$. This differential reflects the higher perceived political risk level in many EMDEs, including sovereign risk, regulatory instability, government counterparty risk, and political uncertainty - as well as more frequent currency mismatches. The differential is nonetheless indicative of a significant potential for mobilising additional private capital towards developing country infrastructure.

Technically, institutional investors - such as pension funds, insurance companies and sovereign wealth funds - have sufficient financial firepower to address climate change (Lin, Halland and Wang, 2018 ${ }_{[8]}$ ), even if only a limited share of their capital would be available for climate-related infrastructure. In OECD countries alone, institutional investors control an estimated USD 92 trillion in assets (OECD, 2018[3])]. Annual official development assistance by development finance ${ }^{3}$ providers and governments amounts to approximately $0.16 \%$ of that - about USD 147 billion $^{4}$ (OECD, 2020[9]), and estimates for philanthropic contributions to developing countries are in the area of USD 30 billion.

As part of the effort to mobilise private finance, MDBs and their private sector arms, the development finance institutions (DFIs), committed to increasing private sector finance by $25 \%-35 \%$ by 2020 (Multilateral Development Banks, 2017 $[10])$. This would have meant moving beyond their traditional role as mainly direct financiers, and become mobilisers of finance. However, there is a disconnect between such 
aspirational objectives and actual outcomes (Bhattacharya et al., 2018[11]), (Lee, 2018[12]), and direct capital mobilisation by MDBs is generally well below 50 cents of private capital mobilised for every dollar of MDB capital deployed (Blended Finance Taskforce, 2018[13]); (Benn, Sangaré and Hos, 2017[14]]). As discussed in this publication, the experience of strategic investment funds (SIFs) and green banks indicates that significantly higher levels of mobilisation are possible - with the right reforms.

In the infrastructure sectors, MDBs and DFIs have, by establishing project development facilities, made an important impact in mitigating the undersupply of early-stage financing for project development and construction. Nevertheless, this impact is dwarfed by demand (Plimmer, 2017 $[15]) .{ }^{5}$ MDBs have also expanded their offer of risk-mitigation instruments for private investors. Yet, they have made only limited investment in infrastructure equity, focusing such investment, instead, on small and medium-sized enterprises in emerging markets. To increase their impact, MDBs and DFIs would need to direct far more capital toward infrastructure projects in the preparation and construction stages (Lin, Halland and Wang, 2018[8]). While loans and risk-mitigation instruments are necessary to support this effort, they are not sufficient, since they are generally provided after a project is fully documented and confirmed as "bankable". Equity investors, by contrast, frequently play a central role in the early stages of a project: the initial technical and financial structuring phase. Development finance providers could mobilise early-stage equity by closer engagement with institutional investors and local strategic investment funds.

This publication argues that efforts to mobilise institutional capital for infrastructure and other long-term investment need to take account of recent and fundamental developments in the global financial sector. In particular, over the last decade, at least 20 countries have established state-sponsored strategic investment funds to co-invest with private partners in priority sectors of their domestic economy. Other countries have established green banks to mobilise private capital for green infrastructure (OECD, $2016[16])$. At the same time, institutional investors are experimenting with internalising their operations and establishing collaborative platforms with other institutional investors for cost-sharing on deal sourcing, due diligence, and other stages of the investment process. These two parallel developments provide an opportunity for blended finance.

With few exceptions, MDBs, DFls, and the facilities and funds established by them, are not part of the new investment platforms and collaborative models established by institutional investors (Basile, Bellesi and Singh, $\left.2020_{[17]}\right)$. There is also only limited co-operation between national strategic investment funds and development finance providers. To be sure, communication between DFls, institutional investors and asset managers is not entirely absent, as demonstrated for example by the European Investment Bank's role as a founding member of the Long-Term Investors Club, and the IFC's partnership with Amundi, Europe's largest listed asset manager, to create a USD 2 billion green bond fund. At the bilateral level, the USD 220 million Danish Climate Investment Fund provides an interesting example. Here, Denmark's DFI ${ }^{6}$ and Ministry of Foreign Affairs collaborated with the Danish pension industry to create a jointly capitalised fund for investing in clean-energy infrastructure in developing countries (Convergence, 2017[2]).

This publication argues that to mobilise private capital at scale, development finance providers may need to redefine relationships with institutional investors, and with investors that are in a position to know and mitigate local risk - such as SIFs and green banks. It contends that a collaborative approach to private capital mobilisation would exploit complementarities between the three types of institutions, and could be operationalised by engagement on collaborative platforms. However, such a collaborative approach faces important obstacles. DFIs and - above all - MDBs in general inhabit a different world from that of the institutional investors, whose capital they seek to mobilise. That separation is likely due not only to obvious differences with regard to mandate, objectives and business practice, but also in terms of governance, skills sets and organisational culture. The main issue is not technical challenges, but the need for a culture change, particularly among development finance providers (OECD, 2018[3]). The publication discusses structural, governance and organisational reforms required to drive a collaborative approach, and thereby enable the mobilisation of institutional investor capital. Whereas there is a literature on the collaborative approach as applied to institutional investors (Singh Bachher, Dixon and Monk, 2016 $\left.{ }_{[18]}\right)$; (Monk, Sharma 
and Sinclair, $\left.2017_{[19]}\right)$, this publication is the first to discuss the implications of this approach for development finance providers.

A caveat is appropriate before moving to further analysis: this publication deals only with the direct mobilisation of institutional investor capital. The catalysing of private investment through regulatory and legal reform, for which MDBs frequently play a critical role, is beyond the scope of this publication. This includes reform of regulatory frameworks for tariffs, user fees and permits for land use, among others, which are key to attracting private investment. The publication also does not address issues of overall national development strategies or national infrastructure plans. In general terms, the mobilisation of private capital for infrastructure makes sense where the investment is both commercially viable and part of a consistent strategy, plan or policy.

The publication is organised as follows. Section 2 discusses the evolution of the new types of local development finance institutions: green banks and strategic investment funds. Section 3 discusses private capital mobilisation, by local and multilateral blended finance institutions, and how these differ in terms of approach and outcome. Section 4 analyses institutional investors' progressive move from an intermediary to a collaborative model of investment. Section 5 explores existing examples of development banks' engagement with local strategic investors and collaborative investment platforms. Section 6 discusses the implications of localisation and the collaborative model for blended finance. Section 7 concludes. 


\section{Local is the new global: Domestic blended finance institutions}

Confronted with large financing needs and limited public revenues, ${ }^{7}$ EMDE governments - and their development partners - have sought to encourage greater private participation in the financing of their capital expenditures. The blending of different sources of public and private funding, with the purpose of crowding-in additional resources for sustainable development, has received increased attention in the policy debate and practice over the last few years (OECD, 2018[1]). The efforts to mobilise resources and ensure their "additionality" go hand in hand with the quest for their effective use and alignment to the objectives of national development strategies and the SDGs. Recent and fundamental developments in the financial landscape suggest that these objectives - additional resources that are used to address development goals - can be pursued at once.

The OECD Development Assistance Committee (DAC) defines blended finance as "the strategic use of development finance for the mobilisation of additional finance towards the sustainable development objectives in developing countries" (OECD DAC, 2017[20]). Additional finance is defined as "commercial finance that does not have an explicit development purpose and that has not primarily targeted development outcomes in developing countries". Private capital already deployed by impact investors for development purposes is, by this definition, not additional, and should not be counted as private capital mobilisation.

At the national level, the last decade has seen a rapid development of new types of blended finance institutions. Many countries have established strategic investment funds (SIFs) to provide equity and quasiequity finance for priority sectors. Other countries, and subnational regions, have set up green banks for lending to green infrastructure projects. As public institutions, or private/semi-private institutions operating within a government-defined mandate, these organisations provide not only finance, but also seek to solve technical and collective action problems. The two new types of institutions both invest to achieve policy objectives and mobilise private capital, while seeking some level of financial return on their investments. Whereas SIFs exist in industrialised as well as in developing countries, only industrialised countries have so far set up green banks. However, South Africa's ongoing establishment of a USD 100 million Climate Finance Facility under the Development Bank of South Africa is a first example of the green bank model applied to an emerging market. ${ }^{8}$

\section{Green banks}

A green bank, or a green investment bank, can be defined as "a publicly capitalised entity established specifically to facilitate private investment into domestic LCR [low-carbon and climate-resilient] infrastructure and other green sectors such as water and waste management" (OECD, 2016 $\left.{ }_{[16]}\right)$. The same publication identifies 13 entities of this kind, most of them founded since $2010,{ }^{9}$ and points to several common characteristics. These include: i) a mandate that focuses mainly on mobilising private LCR investment by interventions that mitigate risks and enable transactions; ii) innovative transactions structures and market expertise; iii) independent authority and latitude to design and implement 
interventions; and iv) a focus on cost-effectiveness and performance. All green banks have a domestic focus. This domestic focus reflects the fact that $90 \%$ of private climate finance investments take place in the country of origin (Climate Policy Initiative, 2014[21]).

Green banks exist, in terms of their level of independence from government, their structure and their functionality, along a spectrum. They are typically established as special-purpose public or quasi-public entities (OECD, 2016 $\left.{ }_{[16]}\right)$. Some operate as administrative units of relevant ministries, including those of Energy, Environment, Finance, and are staffed by public servants. Others function at arm's length from government, as semi-independent and commercially focused state-owned investment organisations, staffed by investment professionals with a background in private equity, infrastructure investing, corporate finance and the renewables sector.

Green banks receive their funding almost entirely from national or subnational government budgets, special appropriations or specific levies. ${ }^{10}$ In a small number of cases, green banks have issued bonds, and may in the future be able to issue government-backed bonds if provided with the legal authority to do so (OECD, 2016[16]). Green banks are local operators, grounded in the social, economic, financial and political realities of their home countries, and are closely connected to local corporate and political networks. They source their projects from local commercial developers, firms and local public authorities.

Green banks focus primarily on the financing of greenfield projects or early-stage clean technology companies. Although green banks are primarily debt providers, they utilise several types of instruments to mobilise private capital. Green banks aim to identify the primary obstacles to investment as perceived by investors and adapt their interventions accordingly. Loans (senior and subordinated) are the most common instrument (OECD, 2016 $[16])$. Other instruments are: direct equity investments (UK Green Investment Bank and Connecticut Green Bank) ${ }^{11}$ mezzanine investments (Connecticut, New York, UK green banks, and CEFC); investments in third-party funds; seeding and management of in-house funds (UK GIB only); risk mitigation instruments; warehousing; and securitisation.

Although green banks target financially viable projects, return requirements differ. Some, including the Green Banks of the UK and New York, aim for full market returns (Green Investment Bank, 2014[22]); (New York Green Bank, 2017[23]). Australia's Clean Energy Finance Corporation (CEFC) has the return target on its loan portfolio dictated by the Australian government, as equal to minimum the five-year Australian government bond rate plus 4-5\% per annum (OECD, 2016 $\left.{ }_{[16]}\right)$. The Connecticut Green Bank, initially a provider of grants and subsidies, has been moving towards a more commercial model (Connecticut Green Bank, 2014[24]).

\section{Strategic investment funds}

More than 20 countries have over the last 15 years established strategic investment funds (SIFs) ${ }^{12}$ to coinvest with private investors in priority sectors of the domestic economy. While having a strong commercial orientation, these funds seek to achieve policy objectives on behalf of the state, according to a "double bottom line". Many are established with the explicit purpose of attracting private co-investment to marginally commercial strata of selected sectors - where the private sector would not invest on its own. As long-term investors with a policy mandate, they are able to: provide scarce "patient" capital, with longer maturities than the private sector is willing to; address first-mover issues as early entrants in new sectors and geographies; solve co-ordination problems by being the lead arranger of deals; and take on earlystage risk for projects that are profitable in the long term. At their best, SIFs are professional financial intermediaries, operating at arm's length from government, and are well placed to take advantage of their strategic position between the state and the market. Many are staffed with diaspora members recruited from global financial centres, and have networks that span domestic government ministries, as well as the domestic and international financial sector. In principle, they are in a position to arrange deals and act as 
local partners for foreign investors with limited knowledge of the domestic market, and to bring projects to market in a format appropriate for institutional investors.

SIFs take their organisational and functional genealogy from the private equity industry. As such, they are primarily equity investors. Similar to private equity funds, SIFs are frequently active initiators and arrangers of deals. SIFs structure deals and pull together investors, and many SIFs focus primarily on greenfield infrastructure. ${ }^{13}$ SIFs take on a diversity of forms along the public-private spectrum. Those with a more public character are managed by public fund management entities operating at arm's length from government, as independent or semi-independent investors within their politically defined mandate. The SIFs of Ireland, Nigeria and Senegal are examples of this approach. At the private end of the spectrum, SIFs are hybrid public-private investment organisations, managed by a private investment manager. The private fund manager is the general partner within a limited liability or similar structure, with other fund sponsors acting as limited partners. An example of this is the European Marguerite Fund, ${ }^{14}$ sponsored by the European Commission, the European Investment Bank (EIB) and the national development banks of six European countries. An intermediate example is that of India's National Investment and Infrastructure Fund (NIIF), where the fund manager is jointly owned by NIIF's public and private investors, and the government's commitment is limited to a minority stake.

SIFs' mandates are frequently established by defining the sectors and geographies that they are allowed to invest in, for which a financing gap has been identified. The SIF is then allowed to operate as a fully commercial investor within these sectors and regions. For example, the Marguerite Fund is mandated to focus on greenfield infrastructure, or brownfield expansion, in the European Union (EU) and EU preaccession countries. By carefully shaping the SIF's mandate, policy makers aim to minimise market distortions, where a SIF could become a direct competitor to private investors and crowd out instead of crowding in private capital. For an overview of SIFs, see (Clark and Monk, 2015[25]) and (Halland, Noël and Tordo, 2016[26]). 


\section{Is the local blend better?}

A paradox of globalisation and the advancement of information and communications technology (TIC) is that geography still matters. The ease of communication and the ability to share information almost instantly has not reduced the value of being "there". Face-to-face contact is still important, particularly where information is imperfect and not easily codified (Storper and Venables, 2004[27]), which is characteristic of most development projects in low and middle-income countries. Even in advanced economies, evidence has shown that fund managers earn higher returns when making investments in securities that are close to home, which suggests they benefit from local information advantages (Coval and Moskowitz, 2011[28]). Additionally, local investments are not exposed to exchange rate risk, if financing and project revenues are in the same currency.

It is useful to explore differences and potential complementarities between the local blended finance institutions reviewed above, and their multilateral counterparts. There appears to be significant differences with regard to capacity for private capital mobilisation. Such differences are likely to be attributable to differences in mandate, structure, governance, staffing, networks, types of financial instruments deployed and modus operandi.

This publication makes use of the term public capital multiplier,${ }^{15}$ to refer to the amount of private investment mobilised per unit of public capital deployed. The multiplier is given as the ratio of commercial (private) capital for every unit of policy-driven capital invested (public capital and impact investors). Additionality refers to this private capital being additional to capital already deployed towards development objectives, for example by impact investors. These two concepts are both relative and hard to measure (Jachnik, Caruso and Srivastava, 2015[29]), (Caruso and Ellis, 2013 ${ }_{[30]}$ ), high multipliers may come at the expense of additionality, and efforts to develop measurement and reporting systems are still ongoing (OECD, 2018[1]). Furthermore, the simple application of multipliers to measure mobilisation could generate perverse incentives for DFls to stay in transactions where they are no longer needed - and are effectively preventing the market from taking over. Notwithstanding, the concepts of multiplier and additionality are useful for discussing the extent and terms on which private capital can be mobilised, while taking into account that any reported measure should be considered as approximate.

\section{Local level mobilisation}

Available evidence indicates that a number of local blended finance institutions are efficient at mobilising private capital. This could be related, in part, to their capacity to help external investors assess local risk. For equity investors, perceived risk and project risk may differ significantly.

Investors build capacity to estimate risks in their home geographies, and employ large teams for that purpose. Conversely, they have less experience in developing countries and employ fewer people there. When less able to be confident on project risks, this translates into risk aversion. ${ }^{16}$ Green banks and SIFs, with their networks in local government and the domestic financial sector, are able to inform foreign partners about local risk, and to help reduce that risk through strategic co-investment. At the same time, many SIFs use their networks in international financial centres to mobilise capital from abroad. Critically, green banks and SIFs, being locally based and staffed, have the "boots on the ground" to engage 
continuously with project developers, local authorities, co-investors, service providers, and other interested parties to a deal or transaction.

Several green banks, including Australia's CEFC and the Connecticut Green Bank, have successfully targeted institutional investors (OECD, 2016 $\left.{ }_{[16]}\right)$. The members of the Green Bank Network had by May 2020 invested USD 14.9 billion to support a total project value of USD 50 billion, resulting in a total average multiplier of 2.4 (Green Bank Network, 2020[31]). Estimates based on other publicly available information paint a somewhat more nuanced picture, with multipliers ranging from 1.8 to 10 (Table 3.1). The more independent and commercially oriented green banks (Connecticut Green Bank, New York Green Bank, and UK Green Investment Bank) appear to have been more successful in mobilising private finance than those functioning as government agencies, such as Australia's CEFC.

Table 3.1. Multiplier estimates for green banks

\begin{tabular}{l|c|c}
\hline \multicolumn{1}{c|}{ Green bank } & Period & Reported multiplier \\
\hline CEFC & $2014-15$ & 1.8 \\
\hline CEFC & $2013-14$ & 2.2 \\
\hline Connecticut Green Bank & 2014 & 3 \\
\hline Connecticut Green Bank & 2013 & 10 \\
\hline NY Green Bank & First 3 transactions, 2015 & 3.6 \\
\hline UK GIB & $2012-15$ & 3 \\
\hline
\end{tabular}

Source: OECD, 2016; Connecticut Green Bank, 2015; CEFC, 2015a, 2015b; NY Green Bank, 2015; UK Green Investment Bank, 2015.

For SIFs, information on multipliers is very limited. Publicly available information indicates that multiplier effects typically range from 4 to 12 dollars of private capital for every dollar of public capital invested, although the range is wider at the upper as well as the lower end. In one prominent example of SIF mobilisation of commercial capital, India's National Infrastructure Investment Fund (NIIF) received commitments from Australia's largest superannuation fund, AustralianSuper, and Toronto-based Ontario Teacher's Pension Plan. The two institutional investors will each commit USD 250 million to NIIF's Master Fund, and will have the right to co-invest up to 750 million each alongside the vehicle in the future (Fernandez, 2019 $\left.{ }_{[32]}\right)$. Other investors into the NIIF Master Fund include Singapore's sovereign wealth fund, Temasek and the Abu Dhabi Investment Authority. In another example, the Nigeria Infrastructure Fund, together with GuarantCo, established InfraCredit to mobilise capital from local pension funds. By targeting local currency, InfraCredit addresses an important obstacle to mobilising capital from foreign investors: that of currency mismatches. Halland et al. estimate some values for SIFs' multipliers based on press releases and other publicly available data, reproduced in Table 3.2 (Halland, Noël and Tordo, $2016[26])$. 
Table 3.2. Capital multipliers of selected funds: preliminary estimates

\begin{tabular}{l|c|c|c|c|c}
\hline \multicolumn{1}{c|}{ Fund1 } & Year & Capitalisation & $\begin{array}{c}\text { Fund } \\
\text { multiplier }\end{array}$ & $\begin{array}{c}\text { Investment } \\
\text { multiplier }\end{array}$ & $\begin{array}{c}\text { Total } \\
\text { multiplier }\end{array}$ \\
\hline Marguerite Fund & 2010 & EUR 710 million & 1 & 11.8 & 11.8 \\
\hline $\begin{array}{l}\text { Ireland Strategic Investment } \\
\text { Fund (ISIF) }\end{array}$ & 2014 & EUR 7.6 billion & 1 & 2.4 & 2.4 \\
$\begin{array}{l}\text { Pan-African Infrastructure } \\
\text { Development Fund (PAIDF) }\end{array}$ & 2007 & USD 625 million & 4.2 & 4 & 16.7 \\
\hline $\begin{array}{l}\text { Fonds Souverain } \\
\text { d'Investissements } \\
\text { Stratégiques (FONSIS) }\end{array}$ & 2016 & Unknown & 1 & 9.6 & 9.6 \\
\hline
\end{tabular}

Notes: ${ }^{1}$ Note from (Halland, Noël and Tordo, 2016[26]): Information on the public versus private share of capital invested at the project level is frequently not publicly available. As a result, estimates shown in this table are indicative only. Funds that are wholly owned by a government have a fund level multiplier of 1 .

2 The multiplier can be calculated at the fund level and at the project investment level. The combination of the two levels results in the total or overall multiplier as follows (Inderst, 2016 $\left.{ }_{[33]}\right)$, (Halland, Noël and Tordo, 2016[26]):

- $\quad$ Fund (or investment vehicle) multiplier = total size of fund or facility/public capital

- $\quad$ Investment multiplier = total invested in projects/fund size

- Total multiplier = total investment volume/public capital

Source: Halland et al. (2016).

\section{Mobilisation by multilateral development finance providers}

In 2016, private capital mobilisation for MDBs' private sector windows (PSW) was 1:1.5 for total direct and indirect mobilisation (Blended Finance Taskforce, 2018[13]). Thus for every USD 1 of PSW resources, USD 1.5 of private finance was mobilised. The direct mobilisation ratio was $1: 0.4$, meaning that one dollar of PSW resources mobilised 40 cents of private finance. The report defines direct mobilisation as financing from a private entity on commercial terms due to the active and direct involvement of an MDB leading to commitment of private finance. ${ }^{17}$ From 2012 to 2015, only USD 81 billion of private capital were mobilised, including mobilisation by bilateral development finance institutions as well as MDBs (Benn, Sangaré and Hos, 2017[14]]). During the same period, total annual official development assistance (ODA) grew from USD 115 billion in 2012 to USD 131 billion in 2015 (OECD, 2020[9]). As these numbers indicate, development finance on average mobilised little private capital as a share of capital deployed.

A thorough review of MDB and DFI initiatives to mobilise private capital would be outside the scope of this publication. ${ }^{18}$ What follows is instead a brief summary, to provide context. There are a number of multilateral initiatives to mobilise private finance for development purposes. Arezki et al. discuss four different models of infrastructure platforms used by MDBs to mobilise private finance for infrastructure (Arezki et al., 2016[34]). These range from credit enhancement, through the EBRD's blended public-private Equity Participation Fund and high-leverage direct investment by the AlIB, to project preparation facilities that are now bearing fruit. ${ }^{19}$ However, whereas the authors recognise the significant capacity of development banks to mobilise private capital, they observe as a major flaw the fact that private investors are largely thought of as passive players and are brought into project planning processes at a late stage, if at all. This precludes the participation of private capital at the project preparation stage and reduces the likelihood that private investors will commit to the project.

It is instructive to consider in some detail the capital mobilisation role of multilateral climate funds (MCFs). Significantly, data from World Resources Institute allows for estimating multiplier effects for these funds. For simplicity and comparability with green banks and SIFs, this publication includes only the three largest MCFs, which all focus mainly on infrastructure. These are the Global Environment Facility (GEF, est. 1992), ${ }^{20}$ the Clean Technology Fund (CTF, est. 2008) ${ }^{21}$ and the Green Climate Fund (GCF, est. 2010). The first two, the GEF and the CTF, were established primarily to aggregate capital from other multilateral 
and bilateral organisations and donor governments. These funds have also sought to mobilise private capital, although that is not their primary mandate. The GCF, on the other hand, was set up specifically to mobilise private capital, but its co-investors have in practice been overwhelmingly public entities. According to the World Resources Institute, co-financing comes from multilateral sources (30\%, 35\% and $47 \%$ for GEF, CTF and GCF, respectively), governments (13\%, 38\% and 14\%), "bilateral and other" $(24 \%, 12 \%$ and $8 \%$ ), and from the private sector (33\%, 14\% and 30\%) (World Resources Institute, 2017[35]). In Table 3.3, the multiplier is given as the ratio of private to public capital, without distinction of source for the public capital. In the column for the multiplier, at the far right, public co-investment is thus included in the denominator. It is worth mentioning that since GEF deploys most of its funding as grants, this is capital that is not recyclable.

\section{Table 3.3. Multiplier for multilateral climate funds}

\begin{tabular}{c|c|c|c|c}
\hline \multirow{2}{*}{ Name } & Co-financing all sources / MCF & \multicolumn{2}{|c|}{ Co-financing } & Multiplier (private / public capital) \\
\cline { 3 - 4 } & & \% Public & \% Private & \\
\hline CTF & 7 & 67 & 33 & 0.40 \\
\hline GEF & 9.7 & 69 & 15 & 0.15 \\
\hline GCF & 2.3 & 30 & 0.27 \\
\hline
\end{tabular}

Note: ${ }^{1}$ Co-financing rates based on figures 7 and 8 , page 30 of WRI (2017).

Source: World Resources Institute, 2017; and authors' calculations.

The experience of MCFs is consistent with that of other blended finance funds majority publicly owned and managed by a public financial institution. This includes the Global Energy Efficiency and Renewable Energy Fund (GEEREF), managed by the EIB, where external capital comes above all from other public entities and impact investors.

\section{Local and multilateral: Different ways of mobilising}

As follows from the above, it is clear that the new types of local blended finance institutions (some green banks and most SIFs) on average achieve far higher multipliers than do multilateral development finance providers. While publicly available information is insufficient for a comparative analysis of additionality, it can be concluded that successful "locals" engage higher proportions of commercial capital. Why is this? It would be beyond the scope of this publication to discuss the variety of organisational and governance arrangements pertaining to MDBs. However, for a more manageable format, it is illustrative to compare green banks and strategic investment funds with MCFs. MCFs are essentially multilateral financial institutions, and have been set up with the specific purpose of mobilising external capital for climate finance. For the purposes of this publication, we consider them as representative of the multilateral approach to private capital mobilisation.

Contrary to green banks and SIFs, MCFs are closely related by their structure, governance, organisation and functionality to other international public bureaucracies, as represented by MDBs and the United Nations (UN) system. MCF funding comes almost exclusively from member governments, either directly, through MDBs, or via other climate-focused public organisations. Their administrative and governance structures tend to mirror those of other multilateral institutions and multilateral development banks. As such, the CTF is governed by a 32-member council consisting of country representatives, with equal representation from developed and developing countries. It has the World Bank as its trustee and is hosted at the World Bank. The Green Climate Fund similarly has a board consisting of 24 country representatives, equally divided between developed and developing countries, with a secretariat based in Songdo, Korea. 
In functional terms, MCFs also have similarities to MDBs. MCF projects are sourced mainly from the MDBs, the UN organisations, government agencies, and other national or regional public organisations. Project implementation is correspondingly undertaken mainly by international or national public entities, with a small share of private sector participation.

\section{Table 3.4. Comparative characteristics of blended finance institutions}

\begin{tabular}{|c|c|c|c|}
\hline & Green banks & Multilateral climate funds & SIFs \\
\hline Ownership & $\begin{array}{l}\text { Wholly-owned and funded by } \\
\text { national or subnational } \\
\text { governments. }\end{array}$ & $\begin{array}{l}\text { Administered by a } \\
\text { designated secretariat, either } \\
\text { UNFCCC or MDBs, with } \\
\text { board input from donor } \\
\text { countries. }\end{array}$ & $\begin{array}{l}\text { Sovereign entities, fully owned and } \\
\text { capitalised by countries; or public-private } \\
\text { limited liability structures. }\end{array}$ \\
\hline $\begin{array}{l}\text { Sources of } \\
\text { capital }\end{array}$ & Mostly budget appropriations. & $\begin{array}{l}\text { Contributions by member } \\
\text { governments / donors. }\end{array}$ & $\begin{array}{l}\text { Fully public (budget transfers), or invested } \\
\text { by combination of public investors } \\
\text { (governments) and private investors. }\end{array}$ \\
\hline Management & $\begin{array}{l}\text { In-house management, with } \\
\text { public or private sector } \\
\text { characteristics depending on } \\
\text { institution. }\end{array}$ & $\begin{array}{l}\text { Frequently managed by } \\
\text { MDBs, or other public } \\
\text { agency. }\end{array}$ & $\begin{array}{l}\text { Semi-independent public management } \\
\text { entity, or managed by private general } \\
\text { partner. }\end{array}$ \\
\hline $\begin{array}{l}\text { Investment } \\
\text { process }\end{array}$ & $\begin{array}{l}\text { Locally sourced projects, from } \\
\text { public entities and developers, } \\
\text { occasionally engage in } \\
\text { secondary market creation. }\end{array}$ & $\begin{array}{l}\text { Deal origination from partner } \\
\text { institutions. } \\
\text { Periodic investment approval } \\
\text { process. }\end{array}$ & $\begin{array}{l}\text { Deal origination from direct sourcing, from } \\
\text { developers, public and commercial partner } \\
\text { institutions. } \\
\text { Continuous investment approval process. }\end{array}$ \\
\hline $\begin{array}{l}\text { Funding } \\
\text { instruments }\end{array}$ & $\begin{array}{l}\text { Mostly debt, some equity and } \\
\text { quasi-equity. May provide } \\
\text { guarantees. }\end{array}$ & $\begin{array}{l}\text { Primarily concessional } \\
\text { financing, loans and grants. }\end{array}$ & $\begin{array}{l}\text { Equity / quasi-equity, limited amount of } \\
\text { debt. }\end{array}$ \\
\hline $\begin{array}{l}\text { Investment } \\
\text { decision } \\
\text { criteria }\end{array}$ & $\begin{array}{l}\text { Commercially viable green } \\
\text { projects where green bank can } \\
\text { make investment happen by } \\
\text { solving co-ordination problems, } \\
\text { share risk, and provide debt, } \\
\text { sometimes equity. }\end{array}$ & $\begin{array}{l}\text { Climate projects in sectors } \\
\text { and geographies that are not } \\
\text { yet commercially viable, } \\
\text { demonstration effects, } \\
\text { replicability. }\end{array}$ & $\begin{array}{l}\text { Commercially viable projects where market- } \\
\text { or government failures inhibit private } \\
\text { investment. SIF can make investment } \\
\text { happen by sourcing and structuring new } \\
\text { projects, sourcing capital from private } \\
\text { investors, provide equity, and solve co- } \\
\text { ordination problems between foreign } \\
\text { investors and local government. }\end{array}$ \\
\hline Governance & $\begin{array}{l}\text { Boards with representation of } \\
\text { local senior public servants and } \\
\text { private sector executives. }\end{array}$ & $\begin{array}{l}\text { Large member boards of } \\
\text { representative country } \\
\text { delegates, often from public } \\
\text { sector finance institutions. }\end{array}$ & $\begin{array}{l}\text { Boards with mix of public and private } \\
\text { representatives. } \\
\text { Investment committees composed mainly of } \\
\text { investment professionals and sector } \\
\text { experts. }\end{array}$ \\
\hline Regulation & $\begin{array}{l}\text { Not structured and regulated as } \\
\text { banks. Some are ring-fenced as } \\
\text { companies, others are } \\
\text { ministerial units. }\end{array}$ & $\begin{array}{l}\text { Given their multilateral } \\
\text { nature, these funds are not } \\
\text { subject to a country-level } \\
\text { regulatory body, but by an } \\
\text { internal or third party } \\
\text { appointed by the fund's } \\
\text { secretariat or board. }\end{array}$ & $\begin{array}{l}\text { SIFs may be regulated by special law or by } \\
\text { existing investment fund law and } \\
\text { regulations. }\end{array}$ \\
\hline $\begin{array}{l}\text { Performance } \\
\text { reporting }\end{array}$ & $\begin{array}{l}\text { Reports investment returns and } \\
\text { impact outcomes (economic, } \\
\text { environmental, social returns) } \\
\text { Performance is gauged on the } \\
\text { ability to meet the mandate and } \\
\text { obligation of the public entity } \\
\text { backing the green bank. }\end{array}$ & $\begin{array}{l}\text { Returns often reported on } \\
\text { "impact", and program } \\
\text { outcomes and success } \\
\text { measures. } \\
\text { Performance is gauged on } \\
\text { multiplier effect of outside } \\
\text { capital, mostly public capital. } \\
\text { Few exits realised or } \\
\text { reported. }\end{array}$ & $\begin{array}{l}\text { Returns reported on commercial and } \\
\text { financial metrics, such as IRR, but include } \\
\text { the double bottom line (economic, } \\
\text { environmental, social). } \\
\text { Performance is gauged on realised returns, } \\
\text { and portfolio exits / commercial success. }\end{array}$ \\
\hline
\end{tabular}

Source: Authors, based on publicly available sources. 
As reflected in Table 3.4, SIFs, as well as the more commercially oriented green banks, have a genealogy that is very different from MCFs. Starting with their boards and investment committees, through executive management, down to the operational staff, these organisations are staffed with investment professionals recruited overwhelmingly from the private sector. They operate within a politically defined mandate, but the decision process for individual investments is designed to be insulated from public bureaucracies and political influence. SIFs frequently have strict limits to government representation on their boards, and may have prohibitions on government representation on their investment committees. The fact that they operate - within their mandate - on a commercial basis, and are managed by executives with an understanding of the private financial sector, is likely to inspire trust amongst private investors that business decisions will be taken on a commercial basis. As locally based long-term investors they are deeply embedded in local private sector and government networks, and have the capacity to engage directly and continuously with developers and other private sector counterparts at every stage of the investment lifecycle. As local investors, their ability to assess risk is founded on an understanding of local markets, as well as local political, economic and other circumstances. Therefore, their capacities are likely to be perceived by foreign investors as complementary.

Whereas MCFs have had limited success in mobilising private finance, their ability to operate on subcommercial terms has allowed them to incubate new markets and drive down technology costs in the countries where they operate. On the other hand, many SIFs have been successful in mobilising private capital, but as commercial or near-commercial investors, their ability to enter incipient and yet subcommercial markets is, compared to MCFs, more limited. Some SIFs, when operating near the fully commercial spectrum of investment opportunities, may invest with lower levels of additionality. 


\section{Localising global investors through collaboration}

The mobilisation of global private investors for blended finance projects is not constrained by a dearth of capital. In a low interest-rate environment, investors are left with few comfortable options. Hence, there is an appetite for exploring new investment opportunities outside of the core advanced economies. Public securities markets in emerging economies may be attractive in this regard, but many remain underdeveloped and limited in new opportunities. Here, blended finance is compelling. However, blended finance is a highly localised activity. The challenge is how to localise global investors. One option is through collaboration platforms, where like-minded institutional investors come together to pool resources and expertise to co-invest, taking advantage of different partners' informational and/or geographical advantages. As such, there is a growing interest among pension funds, sovereign wealth funds, and family offices in collaborating through new co-investment platforms. Such platforms provide a possible solution to the blended finance conundrum.

\section{The benefits and challenges of collaboration}

There are at least six benefits of peer-to-peer collaboration (Singh Bacher, Dixon and Monk, 2016 ${ }_{[18]}$ ). First, in taking one partner's locational advantages in identifying and monitoring projects on the ground, the co-investment platform may garner higher investment returns than an at-distance investor may achieve. Second, in pooling resources, institutional investors bolster returns by sharing the costs of due diligence, research and monitoring. Third, collaboration platforms may provide better deal flow, as the local partner can identify, source and validate investment projects, which may otherwise be difficult to access for at-distance investors. Fourth, collaboration provides investors with diversification opportunities. Fifth, collaboration through a peer-to-peer platform provides an opportunity to bypass conventional intermediaries, thus retaining governance rights and therefore more direct control and oversight of investments. Sixth, the local partner of the collaboration, such as a national strategic investment fund, can minimise headline risk and mitigate political risk. This is particularly relevant for investing in low and middleincome economies.

\section{Types of collaborative platforms}

Singh Bachher et al. identify three types of collaborative platform (Singh Bachher, Dixon and Monk, 2016[18]]. Each offers a different degree of commitment and organisational sophistication. The first type is the alliance. An investment alliance is a loosely affiliated group of investors that come together around a particular investment theme. The objective of this platform is to informally institutionalise collaboration and co-investment without reverting to a dedicated legal structure or external organising body. The second type is the syndicate, which is a formal alliance around an investment theme. With a syndicate, like-minded investors enter into a formal agreement via an independent intermediary. The final type is the seed, which is characterised by a formal legal structure. In effect, collaboration in this case consists of a group of 
investors coming together and establishing a wholly owned asset manager that invests on their behalf subject to a specific investment theme.

Investments in less-developed markets, where blended finance is focused, may require a formally structured platform to mitigate information asymmetries more prevalent in this form of investment. In this case, a syndicate or seed is needed to help "translate" the local to the global. In fact, India's SIF, the NIIF corresponds largely to the "seed" model, with a new management company seeded and jointly owned by the NIIF's investors. Moreover, a locally based investor such as a SIF could be a key facilitator to allow an alliance to function effectively in such settings. Monk et al. describe some of the existing platforms where institutional investors have joined forces with local partners, and the investments generated from these partnerships (Monk, Sharma and Sinclair, 2017 $\left.7_{[19]}\right)$.

A key feature of the collaborative models outlined here is that they are not exclusive. It is critical that investors have a common interest and common goal, but investors do not have to be the same kind of institution. A pension fund can partner and invest alongside a sovereign fund, or an endowment. What this means is that alliances, syndicates and seeds can be formed around a diverse set of institutional investors. By that logic, this could include MDBs and DFIs. 


\section{The collaborative engagement of multilateral development finance providers}

In a small number of cases, MDBs have engaged directly with the establishment and operations of locally or regionally based strategic investors. Similarly, development banks in some rare cases participate on collaborative institutional investor platforms. These early experiences may be precursors to broader MDB collaborative engagement and merit some attention.

One example, the Marguerite Fund, is sponsored and co-funded by the European Commission, the European Investment Bank (EIB), and several major European public financial institutions. The Marguerite structure consists of three funds, Marguerite I, Marguerite II, each of about EUR 700 million, and Marguerite Pantheon. Marguerite invests in greenfield infrastructure in the EU and pre-accession countries. The fund permits its development bank sponsors to convert part of their capital to early-stage infrastructure equity, with a limited share of private capital participation at the fund level.

Another example, The Philippine Alliance for Infrastructure (PINAI) is a USD 625 million 10-year closedend SIF. It is sponsored and co-funded by the Asian Development Bank (ADB), jointly with the Philippines' Government Service Insurance System Fund (GSIS), the Netherlands' Algemene Pensioen Groep (APG), and Macquarie Infrastructure and Real Assets (MIRA), which manages PINAI. PINAI is a commercial investor in Philippine infrastructure, with $4 \%$ of its capital provided by the ADB. Privately managed by MIRA, PINAI has so far invested primarily in brownfield assets.

Marguerite and PINAI illustrate the broad scope of possibilities for MDB engagement. Although both funds are managed by an independent private manager, Marguerite has a far narrower mandate, focusing exclusively on greenfield infrastructure and in some instances brownfield expansion. Marguerite's capital comes overwhelmingly from its development bank sponsors, with private co-financing taking place mainly at the project level. Although Marguerite is privately managed and aims for fully commercial returns, the high level of public capitalisation permits a certain level of public control over the mandate. The mandated focus on greenfield - for which private capital tends to be in short supply - is in turn likely to translate to a high level of additionality.

PINAI, on the other hand, as a manager of pension capital, has a fiduciary duty to its investors to invest on purely commercial terms. The selection of an asset manager for PINAI with a relatively conservative reputation, MIRA, is likely to have underpinned the confidence of the two participating pension funds, and thus helped mobilise capital from these institutional investors. On the other hand, an overweight on brownfield investments is likely to mean a lower level of additionality for PINAI than for Marguerite.

As follows from the discussion above, the collaborative platforms of institutional investors are characterised by the near total absence of MDB or DFI participation. Nevertheless, there is at least one exception, the LongTerm Investors Club (LTIC), where the European Investment Bank is a founding partner. The LTIC lists among its achievements the Marguerite Fund, discussed above, and InfraMed, a EUR 385 million Infrastructure Fund dedicated to long-term investment in the infrastructure of the Mediterranean countries. Contrary to other collaborative platforms, the Long-Term Investors Club is composed mainly of state-owned financial institutions. 


\section{Re-conceptualising blended finance through collaboration}

To mobilise private capital at scale, development finance providers may need to redefine relationships with institutional investors, and with local strategic investors such as strategic investment funds and green banks. These relationships would at best exploit complementarities between the three types of institutions, and could be operationalised by engagement on collaborative platforms. Figure 6.1 below illustrates the challenge. The three key relationships are illustrated by lines between the three circles. The third type of relationship, between development finance providers and institutional investors, will be addressed at some length.

Figure 6.1. Key relationships for MDB and DFI collaborative engagement

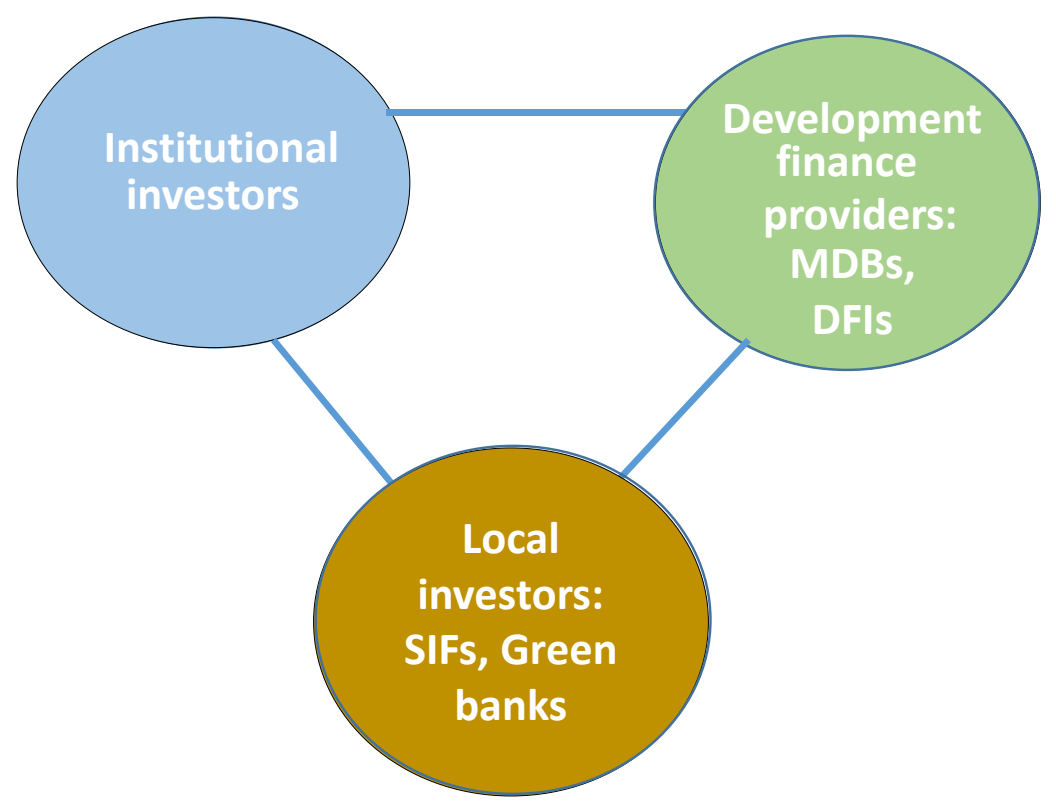

Source: Authors' own elaboration.

Relationship 1: Development finance providers - local strategic investors. As holders of public capital, MDBs and DFls could convert assets into "patient equity" by deploying capital through well-performing strategic investment funds. They can do this by providing loans to help governments capitalise their strategic investment funds, by capitalising the funds directly or by co-investing at the project level. By directing capital to the strongest performers, each entity would be in a position to promote integrity and encourage competition (Lin, Halland and Wang, 2018[8]). By deploying capital through local strategic investors, MDBs and DFIs could direct more equity toward infrastructure projects in the preparation and construction states, when the private sector invests less. 
Relationship 2: Institutional investors - local strategic investors. This type of relationship is documented an analysed at length in (Monk, Sharma and Sinclair, 2017 $[19])$. The authors show how collaborative platforms provide a venue for exploiting complementarities between large institutional investors and local investors. For institutional investors, the local partner is a potential source of project pipeline. It has the knowledge to assess and mitigate local risk, and engage continuously with local government and private sector counterparts. Many institutional investors have limited capacity for infrastructure investment, and SIFs provide complementarity by specialising in infrastructure. For the local partner, foreign institutional investors represent a source of capital, enabling the local investor to engage at greater scale than would otherwise be possible.

Relationship 3: Development finance providers - institutional investors. In their quest to mobilise capital from institutional investors, which are the challenges that MDBs and DFIs need to address? According to (Bhattacharya et al., 2018[11]), MDBs "are trying to respond [to demands for mobilising private capital], but human and financial constraints and unclear and expanded mandates from shareholders are holding them back". It is useful to consider these challenges in the light of the four hurdles to collaboration described in (Singh Bachher, Dixon and Monk, 2016[18]]): structure, human resources, governance, and institutional characteristics. For several of these hurdles, MDBs could draw on the capacity of their private sector arms, the DFIs.

- Structure through which deals are shared and monitored: In development finance, multilateral involvement with an infrastructure project generally starts when the host government approaches a development bank to initiate the investigation and preparation of a project. Private investors are frequently the last parties to be brought into the process (Arezki et al., 2016 ${ }_{[34]}$ ). Institutional investor collaborative platforms, on the other hand, source projects from a variety of sources, including locally based strategic investors, other partners on the platforms, developers, as well as governments. To work efficiently with institutional investors, MDBs and DFIs may need to widen their scope of sourcing deals, share these deals at an early stage with institutional investors, and work directly with institutional investor partners for monitoring. Such engagement could take place through MDB and DFI participation on collaborative platforms.

- Human resources: MDBs are staffed with individuals from a variety of professional backgrounds, providing them with a high level of sector-specific expertise in many areas. On the other hand, few MDB professionals have a background from the private financial sector, and may not possess an in-depth understanding of finance. For efficient engagement on collaborative platforms, development finance providers may need to staff up with professionals that speak the language of private finance, while retaining the type of sector-specific expertise and development focus represented by the current type of staffing. MDBs' private sector arms, the DFIs, recruit extensively from the private financial sector, and their private sector skills and experience could be deployed to engage with collaborative platforms.

- Governance and regulatory requirements: MDB and DFI governance differs from standard corporate governance principles with which private investors are familiar. As the G20 Eminent Persons Group has pointed out, MDBs frequently have significant overlap between board and management responsibilities, and MDB board appointments emphasise country representation rather than financial sector experience. In contrast, private investment organisations emphasise the independence of management with regard to individual investment decisions (Clark and Urwin, $2008_{[36]}$ ), relevant financial sector and business experience of board directors, and a high level of representation of independent directors on their investment committees and other board committees. For MDBs to work efficiently with institutional investors on collaborative platforms, they may need to follow the example of successful SIFs and green banks in bringing board composition, and governance requirements in general, more into line with that of private investment organisations - while continuing to function within a policy-defined mandate. 
- Mitigating different institutional characteristics: Development finance providers tend to be riskaverse institutions, and decision processes therefore can take a long time. To engage productively with institutional investors, on collaborative platforms and otherwise, MDBs could be well served by developing organisational-, governance-, and human resource capacity to assess and bear risk on commercial terms, similarly to private investors. Currently, there are few incentives for MDBs to work with institutional investors, and risk-aversion works against this option.

In addition to these four hurdles, we propose a fifth:

- Going from a push strategy to a pull strategy: Institutional investors are frequently skeptical about MDBs, and about "double bottom lines" in general. They have fiduciary responsibilities, and are concerned that projects pitched by MDBs are too small, not commercial or too high risk, and that MDBs do not have routines to sort things out quickly "if something goes sideways". To attract interest from institutional investors, MDBs and DFls need to find out what these investors' concerns are, and help address these concerns in the sectors and regions where the MDB wishes the institutional investor to invest.

As follows from the comparative review in Section 3 above, institutions that have successfully mobilised private capital tend to be similar in their structure to private investment organisations. They exhibit a high level of operational independence and are insulated from political interference in individual investment decisions - while functioning within a politically defined mandate.

On the other hand, the landscape of blended finance as it exists today is the result of decades of institutional development, starting from foundation of the World Bank (and the International Monetary Fund [IMF]) at the Bretton Woods conference in 1944, or even before. It is useful to abstract for a moment from this historical inheritance and ask: assuming a tabula rasa, what properties should a blended finance institution have, to be able to mobilise institutional capital? Such properties may include:

- Ability to add value for institutional investors by identifying and help address the concerns of these investors, and the bottlenecks that they perceive to investing in borderline regions and sectors.

- Ability to inspire investor confidence that investments undertaken by blended finance are based on commercial principles of return maximisation.

- Well-defined investor protections for private co-investors, grounded in the blended finance institution's mandate, governance and practice.

- Capacity to undertake due diligence and risk assessment as competently as the most qualified actors in the private financial sector, including the assessment of local risk that is hard to evaluate for foreign investors.

- Ability to operate within private sector time scales, where delays frequently translate directly into financial losses.

- Ability to assist institutional investors in accurately assessing risks in new sectors and geographies.

- Ability to participate actively and productively on co-operative platforms for long-term investors.

- Ability to innovate and take calculated risk, based on sound financial and business principles.

- Ability and skills to complement private finance at relevant stages of the investment cycle. For example, guarantees may not be sufficient to mobilise private capital for infrastructure finance if capacity for project development is lacking.

Additionally, development finance providers may need to develop the ability to deploy the right balance of equity, debt, guarantees and other financial instruments. Currently, MDBs are overwhelmingly providers of debt, and have recently been scaling up their already significant capacity to issue guarantees (Basile, Bellesi and Singh, 2020[17])]. Equity is nearly absent from the MDB portfolios, as well as from the portfolios of national development banks. Whereas MDB private sector branches, the DFIs, undertake a limited 
amount of equity investment, this does not take place at sufficient scale to be able to engage broadly with large institutional investors.

To become equity investors and acquire the necessary ability to assess and manage risk, development finance providers may need to undertake significant institutional and governance reforms, in line with the elements discussed above. However, some of these properties may not be straightforward to combine with the mandates, governance systems, skills set and modus operandi of existing development finance providers. How then to go from the current status quo of inefficient mobilisation of institutional capital to a situation where this actually works? One option would be for donor governments and multilaterals to undertake a thorough inquiry, jointly with large institutional investors, to firmly establish precisely the type of properties outlined above. They could then work backwards from the list of desired properties, towards a set of reform proposals to bring development finance providers more into line with requirements for working efficiently with institutional investors. Such a process may seem like a tall order, some would say unrealistic. Yet, after several years of limited success with the mobilisation of private capital, it may be worth considering whether such deep structural changes are the only way to conceivably curb climate change and achieve the sustainable development goals, given the amount of private investment that this requires.

It is important to emphasise that MDB reform towards a more private-sector oriented model runs the risk of reducing the additionality of MDB capital. If commercial returns become prioritised above economic, environmental and social impact, MDB investments could end up crowding out rather than of crowding in private capital. Instead, MDB capital needs to be deployed strategically within individual deal structures, to enable private investors to engage in regions and sectors where they would not otherwise go.

Finally, some geographies, or sectors within specific geographies, will continue to be the remit mainly of public finance, impact investors and philanthropy. In contexts where the return-risk bargain is unfavorable to commercial private investment, or scale is too small for large investors, MDBs and DFls would be well served by not expending resources on seeking institutional investor interest. In their efforts to mobilise capital from institutional investors, MDBs and DFIs should instead focus on sectors and regions where participation by institutional investors is plausible. This would also serve to protect MDB's AAA credit ratings, while expanding blended finance in scenarios where this can be done at a scale relevant to curbing climate change. The set of sectors and regions that are investable on commercial terms is in constant flux, and development finance providers could use their presence on collaborative platforms to help map this changing landscape. Furthermore, it may be possible to securitise certain assets even in relatively highrisk environments, if combined with risk mitigation. 


\section{Conclusions and further research}

Development finance providers have rightly increased their efforts to mobilise private capital, essential to the achievement of the sustainable development goals. However, although private capital has been mobilised, much of this is from impact investors and hence already available for development purposes (Convergence, $2017_{[2]}$ ). Furthermore, the amount of private capital mobilised is small as a share of total MDB and DFI capital deployed. Finally, MDB attention to blended finance has largely focused on financial instruments, such as guarantees and green bonds. This publication proposes that, to expand blended finance, MDBs would to a greater extent need to focus on institutional aspects related to the collaboration with institutional investors and local strategic investors.

Available evidence indicates that local strategic investors - green banks and strategic investment funds are more efficient than development finance providers at mobilising private capital, including from institutional investors. This publication suggests that MDBs and DFIs could significantly strengthen their capacity for private capital mobilisation by redefining their relationship with institutional investors and local strategic investors, and engage with these categories of investors on the types of collaborative investor platforms that have recently emerged. Vis-à-vis institutional investors, MDBs would need to go from a push strategy to a pull strategy. By investing through strategic investment funds, MDBs and DFIs could convert some of their lending to equity, particularly for the financing of early-stage infrastructure where private sector investment is limited. To be successful, engagement with institutional investors may require significant reform of development finance institutions - as outlined in the previous section. MDBs would need to change their financing models, which would require reforms of mandates and internal incentive structures (OECD, 2017[37]).

The role of institutional investors, including SIFs, in adopting the collaborative model has been studied see (Monk, Sharma and Sinclair, 2017 ${ }_{[19]}$ ), (Monk and Sharma, 2018[38]). However, the role of MDBs and DFIs in mobilising institutional investor capital, by using the collaborative model in emerging economies, has not been looked at in detail. There appears to be great potential for these actors to play a significant role, by adopting this framework and evolving their traditional function.

This publication has provided some preliminary ideas for increasing MDB and DFI mobilisation of capital from institutional investors. Further research would dig deeper into the DNA of development finance providers as compared to institutional investors and local strategic investors. It would seek to develop solutions based on a detailed articulation of these institutions' comparative advantages. 


\section{Notes}

1 Such barriers may include: collective action challenges; lack of funding and capacity for project preparation; investors' imperfect information about emerging markets and limited familiarity infrastructure investments; and lack of domestic and foreign long-term capital.

2 This refers to the investments required to meet all infrastructure investment needs in a way that is sustainable, for development needs as well as to address climate change.

${ }^{3}$ This publication uses the term "development finance providers" to refer jointly to multilateral development banks, multilateral development finance institutions, and bilateral development finance institutions.

${ }^{4}$ Constant 2017 USD.

${ }^{5}$ Reflecting private sector aversion to early-stage risk, the total number of shovel ready projects worldwide has held steady in recent years (Plimmer, 2017 $[15])$, even though investor interest in infrastructure investment has soared, causing deal values to increase. Moreover, in recent decades more than $70 \%$ of private-sector investment in infrastructure has been channelled to advanced economies (Dobbs et al., 2013[42]).

${ }^{6}$ The Danish Investment Fund for Developing Countries.

${ }^{7}$ Developing countries included in the OECD Revenue Database have a tax-to-GDP ratio of around 17.5\%, almost half the OECD average. For a comparison of public revenues and tax structures see: https://www.oecd.org/tax/tax-policy/global-revenue-statistics-database.htm.

8 In emerging countries, other institutions that share some of the characteristics of green banks are GreenTech Malaysia, Masdar, Tata Cleantech Capital Limited (TCCL) and the anticipated National Bank of Green Finance in Rwanda.

${ }^{9}$ The discussion here is limited to members of the Green Bank Network: the UK Green Investment Bank, Australia's CEFC, the Connecticut Green Bank, the New York Green Bank, Green Tech Malaysia, and Japan's Green Fund. Other green banks are based in several US states, Switzerland and the United Arab Emirates (UAE).

${ }^{10}$ The only exception to this rule is the UK Green Investment Bank, which in 2017 was privatised by sale to a Macquarie-led consortium and re-named as the Green Investment Group. While it was still publicly owned, GIB raised private capital for a separate GBP 181 million offshore wind fund (Schub, Sims and Swann, 2016[43]).

11 The Japanese Green Fund and Masdar also make equity investments (OECD, 2016 ${ }_{[16]}$ ), but are not included here since the discussion is limited to the members of the Green Bank Network.

12 This publication uses the term "strategic investment fund", as per (Halland, Noël and Tordo, 2016[26]) and (Gelb Tordo and Halland, 2017[39]). Dixon and Monk (Dixon and Monk, 2014[40]), (Dixon and Monk, 
2017[41]) and (Clark and Monk, 2015[25]) use the term "sovereign development fund". For funds that are fully state-owned, the terms are largely overlapping and interchangeable. The term of SIF is wider, in that it encompasses regional funds, as well as funds that are capitalised with non-sovereign capital.

${ }^{13}$ SIFs that focus on greenfield infrastructure include, among others, the European Union's Marguerite Fund, the Nigeria Infrastructure Fund, Senegal's Fonds Stratégique d'Investissements (FONSIS).

${ }^{14}$ Marguerite consists of three funds, Marguerite I, Marguerite II, managed by a private investment manager set up specifically for that purpose, and Marguerite Pantheon - run by Pantheon, a global private markets fund investor

${ }^{15}$ Other publications use the term "leverage" to refer to the amount of private capital mobilised by public capital deployment. Since the common use of "leverage" refers to the ratio of debt to equity for an investment, this publication uses the term "public capital multiplier" to avoid confusion.

${ }^{16}$ The authors are grateful to Alexander Shapiro for this observation, in a comment on an earlier publication on Project Syndicate (Lin, Halland and Wang, 2018[8]).

${ }^{17}$ Indirect mobilisation is defined as finance from private entities provided in connection with a specific activity for which an MDB is providing financing, where no MDB is playing an active or direct role that leads to the commitment of private finance.

${ }^{18}$ For such a review, see for example (OECD, 2018[3]) and other OECD reports.

${ }^{19}$ Several multilateral development banks, including the ADB, the IBRD and the World Bank, have established project preparation facilities.

${ }^{20}$ Only a limited share of GEF projects are directly related to infrastructure project financing. The GEF is nevertheless included here for completeness, as one of the three large MCFs.

21 The Clean Technology Fund is the largest of the two Climate Investment Funds, hosted by the World Bank. 


\section{References}

Alexander, D. (2018), How financial products can attract infrastructure capital from institutional investors., McKinsey \& Company, https://www.mckinsey.com/industries/capital-projects-andinfrastructure/our-insights/how-financial-products-can-attract-infrastructure-capital-frominstitutional-investors.

Arezki, R. et al. (2016), "From Global Savings Glut to Financing Infrastructure: The Advent of Investment Platforms", No. WP/16/18, International Monetary Fund, https://www.imf.org/external/pubs/ft/wp/2016/wp1618.pdf.

Basile, I., V. Bellesi and V. Singh (2020), Blended Finance Funds and Facilities - 2018 Survey Results Part II: Development Performance, OECD, https://doi.org/10.1787/22220518.

Benn, J., C. Sangaré and T. Hos (2017), "Amounts Mobilised from the Private Sector by Official Development Finance Interventions: Guarantees, syndicated loans, shares in collective investment vehicles, direct investment in companies, credit lines", OECD Development Cooperation Working Papers, No. 36, OECD Publishing, Paris, https://dx.doi.org/10.1787/8135abde-en.

Bhattacharya, A. et al. (2018), "The New Global Agenda and the Future of the Multilateral Development Bank System", Brookings Institution, Center for Global Development, and Overseas Development Institute, https://www.brookings.edu/research/the-new-global-agendaand-the-future-of-the-multilateral-development-bank-system/.

Blended Finance Taskforce (2018), Better Finance, Better World. Consultation Paper of the Blended Finance Taskforce, http://s3.amazonaws.com/awsbsdc/BFT BetterFinance final 01192018.pdf\#asset:614:url (accessed on 15 September 2020).

Caruso, R. and J. Ellis (2013), Comparing Definitions and Methods to Estimate Mobilised Climate Finance, http://www.oecd.org/env/cc/ccxg.htmwww.iea.org.

Clark, G. and R. Urwin (2008), "Best-practice pension fund governance", Journal of Asset Management, Vol. 9/1, pp. 2-21, http://dx.doi.org/10.1057/jam.2008.1.

Clark, P. and A. Monk (2015), Sovereign Development Funds: Designing High-Performance, Strategic Investment Institutions., https://dx.doi.org/10.2139/ssrn.2667974.

Climate Policy Initiative (2014), The Global Landscape of Climate Finance 2014, http://www.climatepolicyinitiative.org.

Connecticut Green Bank (2014), Innovating, Educating and Activating to Accelerate Clean Energy, https://ctgreenbank.com/wp-content/uploads/2015/12/AnnualReport FINAL 5.4.15SinglePages.pdf. 
Convergence (2017), The State of Blended Finance, https://www.convergence.finance/resource/1qdtFkf5Fq86S4u8U4G8YU/view.

Coval, J. and T. Moskowitz (2011), "The Geography of Investment: Informed Trading and Asset Prices”, Journal of Political Economy, Vol. 109.

Development Committee (2015), Joint Ministerial Committee of the Boards of Governors of the Bank and the Fund on the Transfer of Real Resources to Developing Countries.

Dixon, A. and A. Monk (2017), "A simple typology of sovereign development funds", Vol. The new frontiers of sovereign investment, pp. 83-100, https://researchinformation.bris.ac.uk/en/publications/a-simple-typology-of-sovereign-development-funds.

Dixon, A. and A. Monk (2014), "Financializing development: toward a sympathetic critique of sovereign development funds", Journal of Sustainable Finance \& Investment, Vol. 4/4, pp. 357371 , https://www.researchgate.net/publication/324668621 Financializing Development Toward a Sympathetic Critique of Sovereign Development Funds.

Dobbs et al. (2013), Infrastructure productivity: How to save \$1 trillion a year McKinsey Global Institute McKinsey Infrastructure Practice, https://www.mckinsey.com/businessfunctions/operations/our-insights/infrastructure-productivity.

Fernandez, E. (2019), OTPP, Australian Giant to Invest up to \$2bn in India's NIIF, https://www.infrastructureinvestor.com/otpp-australian-super-commit-up-to-usd2bn-to-niif/.

Gelb Tordo and Halland (2017), "Domestic investment practices of sovereign wealth funds: empirical evidence to inform policy debates", The new frontiers of sovereign investment, Vol. In The new frontiers of sovereign investment, pp. 124-149, http://cup.columbia.edu/book/the-newfrontiers-of-sovereign-investment/9780231177504.

Green Bank Network (2020), Green Bank Network Webpage, OECD, https://greenbanknetwork.org/gbn-impact/ (accessed on 4 May 2020).

Green Investment Bank (2014), UK Green Investment Bank Annual Report and Accounts 2014-15 (print-ready PDF), https://assets.publishing.service.gov.uk/government/uploads/system/uploads/attachment data/ file/436198/green-investment-bank-annual-report-and-accounts-2014-to2015-print-version.pdf (accessed on 10 September 2020).

Halland, H., M. Noël and S. Tordo (2016), "Strategic Investment Funds: Opportunities and Challenges", World Bank Group, https://pdfs.semanticscholar.org/126c/b3accc2b85c484f685761cd0f066f43271ee.pdf? ga=2.7 8448727.2146348315.1568716538-385598692.1568716538.

Inderst, G. (2016), “Public Capital Multipliers”, Unpublished note, Vol. World Bank, Washington D.C..

Jachnik, R., R. Caruso and A. Srivastava (2015), Estimating Mobilised Private Climate Finance: Policy Perspectives, OECD, http://www.oecd.org/env/researchcollaborative.

Lee, N. (2018), More Mobilizing, Less Lending A Pragmatic Proposal for MDBs CGD BRIEF, https://www.cgdev.org/expert/nancy-lee. 
Lin, J., H. Halland and Y. Wang (2018), "A New Approach to Infrastructure Finance", Project Syndicate, https://www.project-syndicate.org/commentary/attracting-private-infrastructureinvestment-by-justin-yifu-lin-et-al-2018-03?barrier=accesspaylog.

Marsh \& McLennan (2017), Closing the Financing Gap Infrastructure Project Bankability in Asia, https://www.mmc.com/content/dam/mmc-web/Files/APRC/aprc closing-the-financing-gap.pdf (accessed on 14 September 2020).

Monk, A. and R. Sharma (2018), "Organic Finance" The Incentives in Our Investment Products, http://ssrn.com/abstract=2696448.

Monk, A., R. Sharma and D. Sinclair (2017), Reframing finance: New models of long-term investment management, Stanford University Press, https://www.sup.org/books/title/?id=27972.

Multilateral Development Banks (2017), Joint MDB Statement of Ambitions for Crowding in Private Finance, http://www.bundesfinanzministerium.de/Content/DE/Downloads/G20Dokumente/Hamburg Genannte Berichte/Joint-MDB-Statement-of-Am.

New York Green Bank (2017), New York Green Bank-2017-business-plan, http://file:///C:/Users/Nahani p/Downloads/nygb-2017-business-plan.pdf (accessed on 8 September 2020).

OECD (2020), Development Finance Data, https://www.oecd.org/dac/financing-sustainabledevelopment/development-finance-data/.

OECD (2018), Making Blended Finance Work for the Sustainable Development Goals, OECD Publishing, Paris, https://dx.doi.org/10.1787/9789264288768-en.

OECD (2018), The Global Picture of Official Development Assistance (ODA), OECD, https://www.oecd.org/dac/financing-sustainable-development/development-finance-data/\#.

OECD (2017), Investing in Climate, Investing in Growth, http://oe.cd/g20climate.

OECD (2016), Green Investment Banks: Scaling up Private Investment in Low-carbon, Climateresilient Infrastructure, Green Finance and Investment, OECD Publishing, Paris, https://dx.doi.org/10.1787/9789264245129-en.

OECD DAC (2017), Blended Finance Principles for Unlocking Commercial Finance for the Sustainable Development Goals, http://www.oecd.org/development/financing-sustainabledevelopment/blended-finance-principles/.

Plimmer, G. (2017), "Investment in infrastructure assets soars to record", Financial Times, https://www.ft.com/content/c841e854-d988-11e6-944b-e7eb37a6aa8e.

Schub, J., D. Sims and S. Swann (2016), Green \& Resilience Banks: How the Green Investment Bank Model Can Play a Role in Scaling up Climate Finance in Emerging Markets, https://climatefinanceadvisors.com/wp-content/uploads/2016/11/GIB FINAL2.pdf.

Singh Bachher, J., A. Dixon and A. Monk (2016), The New Frontier Investors: How Pension Funds, Sovereign Funds, and Endowments are Changing the Business of Investment Management and Long-Term Investing, Palgrave MacMillan. 
Storper, M. and A. Venables (2004), "Buzz: face-to-face contact and the urban economy", Journal of [27] Economic Geography, Vol. 4/4, pp. 351-370, https://doi-org.eres.qnl.qa/10.1093/inlecg//bh027.

UNCTAD (2014), World Investment Report 2014. Investing in the SDGs: An Action Plan, United [4] Nations Conference on Trade and Development, https://unctad.org/en/PublicationsLibrary/wir2014 en.pdf.

World Resources Institute (2017), The Future of the Funds Exploring the Architecture of Multilateral Climate Finance, World Resources Institute, Washington D.C., https://www.mendeley.com/viewer/?fileld=5db93ed6-ba3f-beff-7a635064dd4c5bc4\&documentld=8982c618-602a-35a9-82d8-a3bc94dd5c3c. 